\title{
CHEMICAL CHARACTERIZATION OF THE FATTY ACID COMPOSITIONS AND ANTIMICROBIAL ACTIVITY OF SUMAC (RHUS CORIARIA L.) FRUITS, GROWING NATURALLY IN TURKEY AND SOLD IN HERBALIST MARKETS
}

\author{
TÜRKIYE'DE DOĞAL OLARAK YETIŞEN VE AKTARLARDA SATILAN SUMAK (RHUS \\ CORIARIA L.) MEYVELERININ YA Ğ ASIDİ KOMPOZISYONLARININ KIMYASAL \\ KARAKTERIZASYONU VE ANTIMIKROBIYYAL AKTIVITESI
}

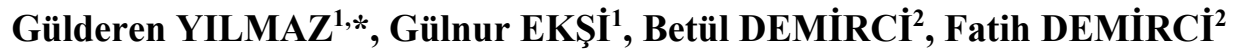

${ }^{1}$ Ankara University, Faculty of Pharmacy, Department of Pharmaceutical Botany, Ankara, Turkey

${ }^{2}$ Anadolu University, Faculty of Pharmacy, Department of Pharmacognosy, Eskişehir, Turkey

\begin{abstract}
Objective: The aim of this study was to compare the fatty acid components and antimicrobial properties of $R$. coriaria L. samples which were sold as powder and grains that show natural distribution in Tunceli and Siirt.

Material and Method: After the seeds were weighed and powdered, fixed oils were obtained by using soxhalet apparatus. Obtained fixed oils were analyzed by GC and GC / MS methods after methylation process. In vitro antimicrobial activity studies of the samples were performed using six different Gram negative and Gram positive bacteria and Candida albicans using EUCAST disc diffusion and CLSI microdilution methods.

Result and Discussion: The main fatty acid components of all samples were determined as oleic acid (42.2 - 43.3\%), linoleic acid (25.2 - 28.5\%) and palmitic acid (18.4-221.5\%), respectively. In vitro antimicrobial activity of fixed oils, such as Escherichia coli NRRL B-3008, Staphylococcus aureus ATCC 6538, S. epidermidis ATCC 14990, Pseudomonas aeruginosa ATCC 27853, Bacillus subtilis NRRL B-A78 A78. Results were compared with standard antimicrobial agents and MIC values $>2.5-0.22 \mathrm{mg} / \mathrm{ml}$. The results were found to be significant in terms of antimicrobial efficacy.
\end{abstract}

Keywords: Antimicrobial, CLSI, EUCAST, GC-FID, GC-MS, Rhus coriaria

\footnotetext{
* Corresponding Author / Sorumlu Yazar: Gülderen Y1lmaz e-mail/e-posta: gulderen_yilmaz@yahoo.com
} 


\section{ÖZ}

Amaç: Bu çalışma Tunceli ve Siirt ilerinde doğal olarak yayllı̧̧ gösteren örnekler ile aktarlarda toz ve tane olarak satılan R. coriaria L. örneklerinin yă̆ asiti bileşenleri ve antimikrobiyal özelliklerini karşılaştırmak amacı ile yapılmıştır.

Gereç ve Yöntem: Tohumlar tartıldıktan ve toz haline getirildikten sonra soksalet kullanarak sabit yağları elde edilmiştir. Elde edilen sabit yağların, metilleme işlemi yapıldıktan sonra, GC ve GC/MS yöntemleriyle eş zamanl olarak analizleri gerçekleştirilmiştir. Sabit yağ numunelerinin in vitro antimikrobiyal aktivite çalışmaları altı farklı Gram negatif ve Gram pozitif bakteri ve Candida albicans'a karşı EUCAST disk difüzyon ve CLSI mikrodilüsyon yöntemleri kullanılarak gerçekleştirilmiştir.

Sonuç ve Tartışma: Tüm numunelerin ana yă̆ asidi bileşenleri, sırasıyla oleik asit (\%42.2 - 43.3), linoleik asit (\%25.2 - 28.5) ve palmitik asit (\%18.4-221.5) olarak tanımland. Sabit yağların in vitro antimikrobiyal aktivitesi, Escherichia coli NRRL B-3008, Staphylococcus aureus ATCC 6538, S. epidermidis ATCC 14990, Pseudomonas aeruginosa ATCC 27853, Bacillus subtilis NRRL B-A78 A78 gibi insan patojenik mikroorganizmalarına karşı gerçekleştirildi. Sonuçlar standart antimikrobiyal maddeler ile karşılaştırılmış ve MIC değerleri > 2,5 - $0.22 \mathrm{mg} / \mathrm{ml}$ belirlenmiştir. Sonuçların antimikrobiyal etkinlik açından kayda değer olduğu görülmüştür.

Anahtar Kelimeler: Antimikrobial, CLSI, EUCAST, GC-FID, GC-MS, Rhus coriaria

\section{INTRODUCTION}

The genus Rhus L. contains more than 130 species belong to Anacardiaceae [1]. Rhus coriaria L. (sumac) is a wild edible species mainly grown in temperate and subtropical regions; in Mediterranean countries, Turkey and near East. Plant grows up to 3-4 $\mathrm{m}$ in height. Mature fruits are reddish-brown in color and have one seed [2]. R. coriaria was used both for its nutritional and medicinal values for centuries by crushing the dried fruits in the Mediterranean and Middle East. About 2000 years ago, the Greek physician Pedanius Dioscorides wrote in the "De Materia Medica" on the therapeutical traits of sumac [3]. In Arabic Palestinian herbal medicine, it was used for cancer, heart diseases, diarrhoea, blood pressure management, intestinal diseases, eye infections, stomachache, kidney and liver diseases, blood sugar management, respiratory infections, smallpox, oral diseases, headache, bites, dermatitides [4], in Turkish traditional medicine for ulcer, blood sugar management, respiratory infections, smallpox, oral diseases, diarrhoea, bleeding and intestinal diseases. $R$. coriaria has increasing economic importance around the world in terms of pharmacology and food preservation. $R$. coriaria was reported as cytotoxic, antimutagenic, antioxidant, antimalarial, antithrombin, antifibrogenic, and antitumorigenic. Beside, sumac is most notable for its potential antimicrobial, antifungal, and antiviral effects [5]. Different parts of $R$. coriaria plant are an abundant source of tannins, phenolic acids, anthocyanins, gallic acid derivatives, flavonoid glycosides such as methyl gallate, kaempferol, and quercetin [4]. It also contains fatty acids, volatiles, organic acids proteins, fibers, vitamins, and minerals. The fruits encompass phenolic compounds like tannins, volatiles, and organic acids, anthocyanins, and fixed oil [2].

In this study, in vitro antimicrobial activity of different fruit fixed oils were performed against five different Gram-negative and Gram-positive human pathogenic bacteria (Escherichia coli NRRL B3008, Staphylococcus aureus ATCC 6538, S. epidermidis ATCC 14990, Pseudomonas aeruginosa 
ATCC 27853, Bacillus subtilis NRRL B-4378) and Candida albicans ATCC 90028 using European Committee on Antimicrobial Susceptibility Testing (EUCAST) disc diffusion and The Clinical and Laboratory Standards Institute (CLSI) microdilution methods.

\section{MATERIAL AND METHOD}

\section{Plant materials}

Fruits of Rhus coriaria were collected from Tunceli and Siirt provinces (Figure 1). Voucher specimens were deposited at the Herbarium of the Faculty of Pharmacy in Anadolu University, Eskisehir, Turkey (ESSE). Plant materials were listed in Table 1.
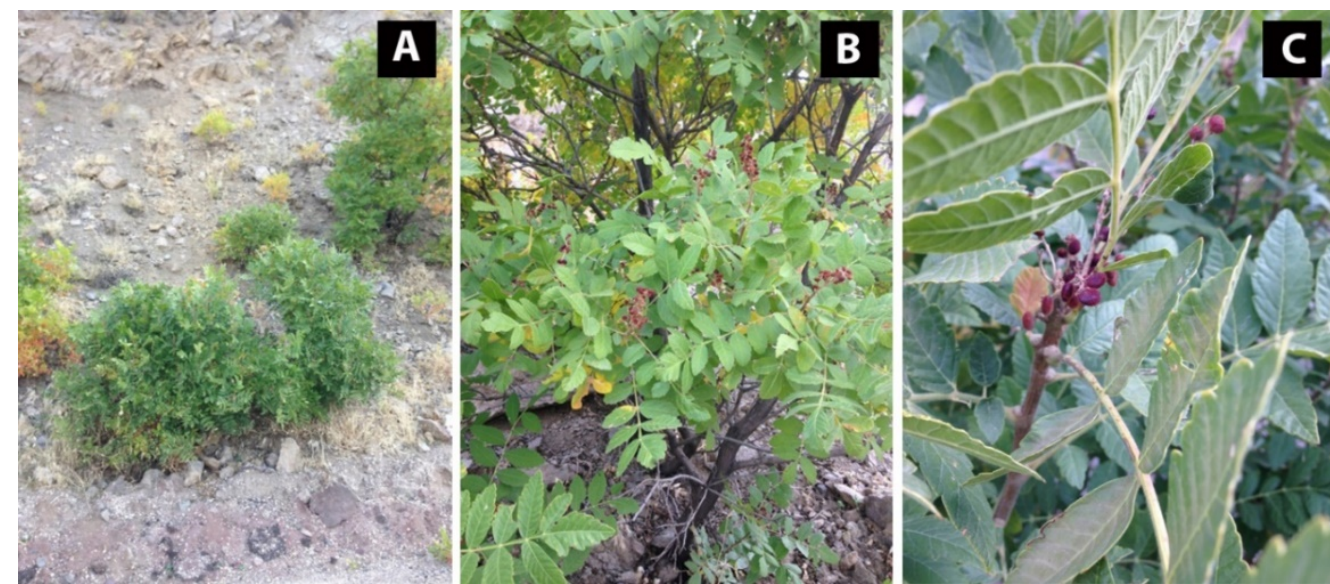

Figure 1. A, B, C Habitus of Rhus coriaria L.

Table 1. Plant samples used in the study.

\begin{tabular}{|l|l|l|l|}
\hline \multicolumn{1}{|c|}{ Code } & Locality and date & ESSE Number & Local Code \\
\hline A (Grain) & Tunceli, Batman Village, 1077 m, 2015 & 34 & DT \\
\hline B (Grain) & Siirt, 895 m, 2015 & 33 & Ds \\
\hline C (Grain) & Ankara, Commercial, 2015 & 32 & $\mathrm{~A}_{1}$ \\
\hline D (Pulverised) & Ankara, Commercial, 2015 & 31 & $\mathrm{~A}_{2}$ \\
\hline
\end{tabular}

\section{Extraction}

The air-dried plant material (10 gr) was crushed and extracted using a Soxhlet apparatus. The resulting oils $(25 \pm 5 \%)$ were dried over anhydrous sodium sulfate prior to further derivatization and bioactivity evaluations. 


\section{Preparation of Fatty Acid Methyl Esters}

The residue was refluxed with $0.5 \mathrm{~N} \mathrm{NaOH}$ solution $(5 \mathrm{ml})$ for $10 \mathrm{~min}$ in methanol. Afterward, $14-20 \% \mathrm{BF}_{3}(5 \mathrm{ml})$ in methanol solution was added via the condenser. Then, the solution boiled for an additional $2 \min .5 \mathrm{ml} n$-hexane was added and boiled for a further $1 \mathrm{~min}$. After the solution cooled an additional $5 \mathrm{ml}$ of saturated $\mathrm{NaCl}$ solution was added and the flask was rotated gently quite a few times. Finally, saturated $\mathrm{NaCl}$ solution was added to float the $n$-hexane solution into the neck of a $1 \mathrm{ml}$ flask and the solution was transferred into a vial [6].

\section{Analyses}

\section{Gas Chromatography (GC)}

Agilent $6890 \mathrm{~N} \mathrm{GC}$ system was used for the $\mathrm{GC}$ analysis. The temperature was set to $300{ }^{\circ} \mathrm{C}$ for a flame ionization detector (FID). The simultaneous auto-injection implemented column (Innowax FSC column, $60 \mathrm{~m} \times 0.25 \mathrm{~mm}, 0.25 \mu \mathrm{m}$ film thickness) was used in an attempt to achieve the same elution order on the GC-MS to fulfill the identical working conditions. FID chromatograms were used to calculate the relative percentage amounts (\%) of the separated compounds.

\section{Gas Chromatography-Mass Spectrometry (GC-MS)}

Helium gas was used as carrier $(0.8 \mathrm{ml} / \mathrm{min}$ gas flow $)$ and the temperature was set for $10 \mathrm{~min}$ at $60{ }^{\circ} \mathrm{C}$ and calibrated to $220^{\circ} \mathrm{C}$ at a ratio of $4{ }^{\circ} \mathrm{C} / \mathrm{min}$, and then set permanently at $220^{\circ} \mathrm{C}$ for $10 \mathrm{~min}$ and at the end conditioned to $240{ }^{\circ} \mathrm{C}$ at a ratio of $1{ }^{\circ} \mathrm{C} / \mathrm{min}$ then set for $20 \mathrm{~min}$ at $240{ }^{\circ} \mathrm{C}$. The split rate was kept at 40:1. The port temperature of injection was kept at $250{ }^{\circ} \mathrm{C}$. MS was kept at $70 \mathrm{eV}$ and the designated mass range was between $\mathrm{m} / \mathrm{z} 35$ and 450. The components of the essential oil were identified by using their relative retention times or by assessment of their relative retention index (RRI) to a series of $n$-alkanes. For the identification of essential oil, Wiley and MassFinder 3, Baser Library of Essential Oil Constituents and also MS literature data was also used [7-11].

\section{Antimicrobial Assay}

Disc diffusion is one of the oldest approaches to antimicrobial susceptibility testing (AST) and remains one of the most widely used AST methods in routine clinical microbiology laboratories. The method is appropriate for testing the majority of bacterial pathogens [12,13]. EUCAST initiated the development of a standardized disk diffusion method calibrated to the harmonized MIC breakpoints. The method comprises the use of Mueller-Hinton agar without supplements for non-fastidious organisms and with $5 \%$ mechanically defibrinated horse blood and $20 \mathrm{mg} / \mathrm{L} \mathrm{b}-\mathrm{NAD}$ for fastidious organisms, a standardized inoculum resulting in confluent growth, an incubation time of 16-20 h, a 
reading guide on how to read zone diameters on individual species-agent combinations and zone diameter breakpoints calibrated to the EUCAST clinical MIC breakpoints [13].

Escherichia coli (NRRL B-3008), Staphylococcus aureus (ATCC 6538), S. epidermidis ATCC 14990, Pseudomonas aeruginosa (ATCC 27853), Enterobacter aerogenes (NRRL 3567), Bacillus subtilis (NRRL B-4378), were used as test bacteria, whereas the human pathogenic yeast Candida albicans (ATCC 90028) was also used in the panel. $15 \%$ glycerol at $-85{ }^{\circ} \mathrm{C}$ was used to store the microorganisms. The Mueller Hinton Broth (Merck, Germany) was used to revitalize the bacteria and yeast at $35-37{ }^{\circ} \mathrm{C}$. For purity check, the bacteria and yeast inoculated on the plates of Mueller Hinton agar (MHA, Mast Diagnostics, U.K.). In this study, a microdilution broth susceptibility assay (REF) was used [14]. Dimethylsulfoxide 25\% (v/v) (DMSO, Carlo Erba) was used to prepare the stock solutions. Dilutions of samples were prepared in a 96-well microtiter plate by using distilled water. The microbial suspensions were standardized in double strength Mueller Hinton Broth (MHB) and Mueller Hinton Agar (MHA) and then each microbial suspension $(100 \mu \mathrm{L})$ was added to the appropriate well. The serial dilutions of the essential oil were used as a negative control. The minimum inhibition concentration (MIC, $\mathrm{mg} / \mathrm{ml}$ ) was determined after incubation at $37{ }^{\circ} \mathrm{C}$ for $24 \mathrm{~h}$. Chloramphenicol was used as standard antibacterial and as Candida positive control Ketoconazole was used. Entire assays were repeated at least 3 times [15-19]. The MIC results are given in Table 3.

\section{RESULT AND DISCUSSION}

From the different fruit samples obtained sumac oils were analysed by using the GC and GC-MS (Table 2) to detect the major fatty acid components, and four bioassays assessed in combination in order to release their antimicrobial effects towards human pathogenic microorganisms (Table 3). The composition and comparative proportions of the sumac fatty acids were clarified with the help of GC and GC-MS analyses. Results of the simultaneous analysis with GC and GC-MS method are given in Table 2. The oleic acid contents changed between 42.2 and $43.3 \%$, the linoleic acid contents were changed between 25.2 and $28.5 \%$ and finally, the palmitic acid content ranged from 18.04 to $21.5 \%$ as main constituents. Oleic $\left(\mathrm{C}_{18: 1}\right)$, linoleic $\left(\mathrm{C}_{18: 2}\right)$, and palmitic $\left(\mathrm{C}_{16: 0}\right)$ acids were the main fatty acids in the sumac oil, respectively. The polyunsaturated fatty acid contents $(18: 2+18: 3)$ of the total fatty acids changed between 25.9 and $29.9 \%$.

The antibacterial effects of the sumac oils with the major components of oleic acid, linoleic acid, and palmitic acid opposed to the standard antimicrobial agent chloramphenicol were given in Table 2 . The oleic acid contents of the oils changed between 42.2 and $43.3 \%$, the linoleic acid between 25.2 and $28.5 \%$ and the palmitic acid ranged from $18.4 \%$ to $21.5 \%$. In this study, oleic $\left(\mathrm{C}_{18: 1}\right)$, linoleic $\left(\mathrm{C}_{18: 2}\right)$, and palmitic $\left(\mathrm{C}_{16: 0}\right)$ acids were found the main fatty acids in the sumac oil. Polyunsaturated fatty acid contents $(18: 2+18: 3)$ were changed between 25.9 and 29.9\%. Staphylococcus aureus was inhibited 
with an intermediate MIC value of $2.5 \mathrm{mg} / \mathrm{ml}$. S. epidermidis was inhibited with a low MIC value of 2.5 $\mathrm{mg} / \mathrm{ml}$, Escherichia coli was inhibited by sumac oils except C with a MIC value of $2.5 \mathrm{mg} / \mathrm{ml}$ while C inhibited the E. coli with a strong MIC value of $0.62 \mathrm{mg} / \mathrm{ml}$. Pseudomonas aeruginosa was inhibited by the sumac oils with a MIC value of $2.5 \mathrm{mg} / \mathrm{ml}$, having much stronger activity than antimicrobial agent chloramphenicol, while Bacillus subtilis was inhibited with a moderate MIC value of 1.25-2.5 $\mathrm{mg} / \mathrm{ml}$.

Table 2. Fatty Acid Compositions of Rhus coriaria L. Fruits identified by GC and GC-MS.

\begin{tabular}{lcccc}
\hline Compound & $\mathbf{A ~ ( \% )}$ & $\mathbf{B ~ ( \% )}$ & $\mathbf{C ~ ( \% )}$ & $\mathbf{D ~ ( \% )}$ \\
\hline Palmitic acid (16:0) & 20.7 & 20.0 & 21.5 & 18.4 \\
Palmitoleic acid (16:1) & $\operatorname{tr}$ & $\operatorname{tr}$ & 0.4 & 0.3 \\
Stearic acid (18:0) & 2.9 & 2.7 & 2.1 & 3.3 \\
Oleic acid (18:1) & 42.5 & 42.4 & 42.2 & 43.3 \\
Elaidic acid (18:1) & 6.5 & 5.0 & 7.2 & 5.1 \\
Linoleic acid (18:2) & 26.2 & 28.5 & 25.2 & 27.6 \\
Linolenic acid (18:3) & 1.0 & 1.4 & 0.7 & 1.2 \\
Arachidic acid (20:0) & tr & tr & 0.7 & 0.8 \\
\hline Saturated & 23.6 & 22.7 & 24.3 & 22.5 \\
\hline Unsaturated & 76.2 & 77.3 & 75.7 & 77.5 \\
\hline Unsaturated/Saturated & 3.23 & 3.41 & 3.12 & 3.44 \\
\hline \multicolumn{1}{c}{ Total } & $\mathbf{9 9 . 8}$ & $\mathbf{1 0 0 . 0}$ & $\mathbf{1 0 0 . 0}$ & $\mathbf{1 0 0 . 0}$ \\
\hline A: Tunceli, B: Siirt, C: Commercial (grain), D: Commercial (pulverised), \%: calculated from FID data, tr: Trace $(<0.1 \%)$
\end{tabular}

Table 3. Minimum inhibitory concentrations of samples $(\mathrm{mg} / \mathrm{ml})$ and antimicrobials $(\mu \mathrm{g} / \mathrm{ml})$ by the microdilution method.

\begin{tabular}{lllllll}
\hline Test samples & $\begin{array}{l}\text { E. coli } \\
\text { NRRL } \\
\text { B-3008 }\end{array}$ & $\begin{array}{l}\text { S. aureus } \\
\text { ATCC } \\
\mathbf{6 5 3 8}\end{array}$ & $\begin{array}{l}\text { S. epidermidis } \\
\text { ATCC 14990 }\end{array}$ & $\begin{array}{l}\text { P. aeruginosa } \\
\text { ATCC 27853 }\end{array}$ & $\begin{array}{l}\text { B. subtilis } \\
\text { NRRL B- } \\
\mathbf{4 3 7 8}\end{array}$ & $\begin{array}{l}\text { C. albicans } \\
\text { ATCC } \\
\mathbf{9 0 0 2 8}\end{array}$ \\
\hline $\mathrm{A}$ & $>2.5$ & $>2.5$ & $>2.5$ & $>2.5$ & $>2.5$ & 0.62 \\
$\mathrm{~B}$ & $>2.5$ & $>2.5$ & $>2.5$ & $>2.5$ & $>2.5$ & 0.31 \\
$\mathrm{C}$ & 0.62 & $>2.5$ & $>2.5$ & $>2.5$ & 1.25 & 1.25 \\
$\mathrm{D}$ & $>2.5$ & $>2.5$ & $>2.5$ & $>2.5$ & $>2.5$ & 1.25 \\
\hline Chloramphenicol & 8 & 4 & 2 & $>64$ & 4 & \\
Ketoconazole & & & & & & 0.25 \\
\hline
\end{tabular}

A: Tunceli, B: Siirt, C: Commercial (grain), D: Commercial (pulverised).

Nevertheless, all the sumac oils exhibited a strong inhibition with a MIC value of $0.62-2.5 \mathrm{mg} / \mathrm{ml}$ against plant pathogens with the exception of sample $S$. epidermidis. Antifungal effects of the $R$. coriaria oils were also examined against the standard antifungal agent Ketoconazole. All examined sumac oils 
displayed weak antifungal effect with a concentration of $1.25 \mathrm{mg} / \mathrm{ml}$, which recommended a strong resistance of a pathogenic fungus, Candida albicans (Table 3). In vitro antimicrobial activity studies of fixed oil samples were performed using six different Gram-negative (E. coli, P. aeruginosa) and Grampositive (S. aureus, S. epidermidis, B. subtilis) bacteria and a fungus C. albicans by using EUCAST disk diffusion and CLSI microdilution methods. The results were compared with standard antimicrobial agents and MIC values $>2.5-0.22 \mathrm{mg} / \mathrm{ml}$ were determined. The results were found to be noteworthy for antimicrobial efficacy (Table 3).

Doğan and Akgül (2005) were extracted the sumac oil by using the cold ether extraction method. Accordingly, oleic acid (34.00 to 40.35\%), linoleic and linolenic acid (33.31 to 35.83\%) and palmitic acid (20.75 to $25.60 \%)$ was shown as the main fatty acids in sumac oil. Polyunsaturated fatty acid (18:2 $+18: 3$ ) contents of the total fatty acids were changed between 34.84 and $37.36 \%$ [20]. Our results were confirmed the previous studies that oleic, linoleic, and palmitic acids are the major fatty acids in sumac fruits [21]. Besides, the oleic acid contents (42.2 to $43.3 \%$ ) is higher, the linoleic acid contents (25.2 to $28.5 \%$ ) is lower, and the palmitic acid content (18.4\% to $21.5 \%$ ) is lower than Doğan and Akgül (2005). The polyunsaturated fatty acid content (25.9 to $29.9 \%$ ) is also lower than the results in Doğan and Akgül (2005). To storage capabilities and for longer shelf life polyunsaturated fatty acid levels are very important, since the polyunsaturated fatty acids are more vulnerable to oxidative degradation and a lower polyunsaturated fatty acid content can probably extend the shelf life [20]. Nimri et al., (1999) have been extracted the $R$. coriaria fruits by using ethanol and the results indicated a wide-ranging of antimicrobial activity which was dedicated to the tannins with a MIC value of 10 to $26 \mathrm{mg} / \mathrm{ml}$ against numerous bacteria [22]. The following work examined the inhibitory effect of ripened and unripened $R$. coriaria fruits against six Gram-positive and six Gram-negative bacteria suggested the extracts were found to be effective against all tested bacteria, especially against Gram positives and the ripened fruits were found to have a stronger antimicrobial activity [23]. In contrast, in our study, the extracts were found to be more sensitive against Gram-negative bacteria. In another work suggested that the dry $R$. coriaria seed found to have an antibacterial effect against Pseudomonas aeruginosa [24] similar to our results. Fruits of $R$. coriaria hydroalcoholic extract were tested against Gram-positive and negative bacteria, S. aureus, B. cereus, E. coli by using a cool percolation method and extract exhibited antibacterial activity against the species tested likewise our results [25]. Water extracts of dried $R$. coriaria fruits exhibited antimicrobial activity against $B$. subtilis, S. aureus, S. enteritidis and E. coli [23]. B. subtilis was found to be more sensitive among Gram-positive bacteria and E. coli was found to be one of the most resistant Gram-negative bacteria. In our study, while S. epidermidis, among Grampositive strain, found to be the most resistant, E. coli was found sensitive to $R$. coriaria fruit extract. Nasar-Abbas \& Halkman (2004) claimed the water extracts of $R$. coriaria fruits presented quit a strong effect against Gram-positive bacteria. In contrast to alcoholic and aqueous extracts from sumac, a 
hydrodistillation extract of dried $R$. coriaria fruits was shown to be ineffective as an antimicrobial agent [26].

As the overall conclusion, the results were found to be noteworthy for antimicrobial efficacy. Results indicate that individual fatty acid contents of $R$. coriaria have been grown in the different provinces of Turkey are variable and potential antimicrobial sources.

\section{REFERENCES}

1. The Plant List Version 1 Web site (2019) accessed January 29, 2019, from http://www.theplantlist.org

2. Brunke, E.J., Hammerschmidt, F.J., Schmaus, G., Akgül A. (1993). The essential oil of Rhus coriaria L. fruits. Flavour and Fragrance Journal, 8, 209-214.

3. Abu-Reidah, I.M., Jamous, R.M., Ali-Shtayeh, M.S. (2014). Phytochemistry, pharmacological properties and industrial applications of Rhus coriaria L. (Sumac). Jordan Journal of Biological Sciences, 4, 233-244.

4. Abu-Reidah, I.M., Ali-Shtayeh, M.S., Jamous, R.M., Arráez-Román, D., Segura-Carretero, A. (2015). HPLC-DAD-ESI-MS/MS screening of bioactive components from Rhus coriaria L. (Sumac) fruits. Food Chemistry, 166, 179-191.

5. Rayne, S., Mazza, G. (2007). Biological activities of extracts from sumac (Rhus spp.). A review. Plant Foods for Human Nutrition, 62, 165-175.

6. Azcan, N., Ertan, A., Demirci, B., Başer, K.H.C. (2004). Fatty acid composition of seed oils of twelve Salvia species growing in Turkey. Chemistry of Natural Compounds, 40, 218-221.

7. ESO 2000. (1999). The complete database of essential oils. Boelens Aroma Chemical Information Service. The Netherlands.

8. Joulain, D., Konig, W.A. (1998). The atlas of spectral data of sesquiterpene hydrocarbons. Journal of Natural Products, 62, 1212-1213.

9. Jennings, W.G., Shibamoto, T. (1980). Quantitative analysis of flavor and fragrance volatiles by glass capillary gas chromatography GC, Academic Press, New York.

10. McLafferty, F.W., Stauffer, D.B. (1989). The Wiley/NBS registry of mass spectral data, Wiley and Sons, New York.

11. Koenig, W.A., Joulain, D., Hochmuth, D.H. (2004). Terpenoids and related constituents of essential oils. Mass Finder 3. In: Hochmuth DH, ed. Convenient and Rapid Analysis of GC MS, Hamburg, Germany, pp 493.

12. Jones, R.N. (1992) Recent trends in the college of American pathologists proficiency results for antimicrobial susceptibility testing, Preparing for CLIA'88, Clinical Microbiology Newsletter, 14, 33-37. 
13. Matuschek, E., Brown, D.F.J., Kahlmeter, G. (2014). Development of the EUCAST disk diffusion antimicrobial susceptibility testing method and its implementation in routine microbiology laboratories. Clinical Microbiology and Infection, 20, 255-266.

14. Croxatto, A., Prodhom, G., Greub, G. (2012). Applications of MALDI-TOF mass spectrometry in clinical diagnostic microbiology. Fems Microbiology Reviews, 36, 380-407.

15. Demirci, B., Toyota, M., Demirci, F., Dadandi, M.Y., Başer, K.H.C. (2009). Anticandidal pimaradiene diterpene from Phlomis ossential oils. Comptes Rendus Chimie, 12, 612-621.

16. CLSI. (2007). Performance Standards for Antimicrobial Susceptibility Testing; Seventeenth Informational Supplement, M100-S17, Clinical and Laboratory Standards Institute, 27(1).

17. Clinical and Laboratory Standards Institute M7-A7. (2006). Methods for Dilution Antimicrobial Susceptibility Tests for Bacteria That Grow Aerobically; Approved Standard-Seventh Edition, CLSI document, 26(2).

18. Clinical and Laboratory Standards Institute M27-A2. (2002). Reference Method for Broth Dilution Antifungal Susceptibility Testing of Yeasts; Approved Standard-Second Edition, CLSI document, 22(15).

19. EUCAST. (2015). European Society of Clinical Microbiology and Infectious Diseases, Antimicrobial susceptibility testing EUCAST disk diffusion method Version 5.0.

20. Doğan, M., Akgül, A. (2005) Characteristics and fatty acid compositions of Rhus coriaria cultivars from southeast Turkey. Chemistry of Natural Compounds, 41, 724-725.

21. Ünver, A., Özcan, M.M. (2010) Fatty acid composition of seed and pericarp of sumach (Rhus coriaria L.) grown wild in different regions of Turkey. Journal of Food, Agriculture and Environment, 8, 31-33.

22. Nimri, L.F., Meqdam, M.M., Alkofahi, A. (1999). Antibacterial activity of Jordanian medicinal plants. Pharmaceutical Biology, 37, 196-201.

23. Nasar-Abbas, S.M., Halkman, A.K. (2004). Antimicrobial effect of water extract of sumac (Rhus coriaria L.) on the growth of some food borne bacteria including pathogens. International Journal Food Microbiology, 97, 63-69.

24. Adwan, G., Abu-Shanab, B., Adwan, K., Abu-Shanab, F. (2006). Antibacterial effects of nutraceutical plants growing in Palestine on Pseudomonas aeruginosa. Turkish Journal of Biology, 30, 239-242.

25. Fazeli, M.R., Amin, G., Attari, M.M.A., Ashtiani, H., Jamalifar, H., Samadi, N. (2007). Antimicrobial activities of Iranian sumac and avishan-e shirazi (Zataria multiflora) against some food-borne bacteria. Food Control Journal, 18, 646-649.

26. Sağdıç, O., Özcan, M. (2002). Antibacterial activity of Turkish spice hydrosols. Food Control Journal, 14, 141-143. 